\title{
Postnatal Ontogeny of Expression of Monocarboxylate Transporters (MCTs) and Two Regulatory Proteins, Basigin and Embigin, in The Epididymis of Male Rat
}

\author{
K. H. Lee
}

Department of Biochemistry and Molecular Biology and Center of Antiaging, Eulji University

\author{
흰쥐의 부정소에서 Monocarboxylate Transporters (MCTs)와 조절 \\ 단백질, Basigin과 Embigin의 생후 발달 과정 동안 발현 양상 \\ 이 기 호 \\ 을지대학교 생화학-분자생물학교실
}

요 약

본 연구는 생후 발달 과정 동안 monocarboxylate transporter(MCT) isoform과 MCT의 발현 조절 단백 질로 알려진 basigin (Bsg)과 embigin의 mRNA 발현을 흰쥐의 부정소에서 부위별로 real-time PCR 방법 을 사용하여 알아보았으며, 에스트로젠과 에스트로젠 수용체 $a$ 의 작용에 의해 MCT1 발현이 조절되 는지를 알아보기 위해 estrogen receptor a knockout (aERKO) 마우스를 이용하여 immunohistochemistry 방법을 통해 탐구하였다. 본 연구 결과는 다양한 MCT isoform (MCT1, 2, 3, 4와 8), Bsg과 embigin의 mRNA 발현이 부정소의 부위별로 연령에 따라 다르게 나타나며, 부정소에서 MCT1 단백질 발현은 corpus와 caudal 부위에서 apical 지역에 한정되어 나타나는 것을 보여 주었다. 또한 부정소에서 MCT1 단백질 발현은 에스트로젠 수용체 $\mathrm{a}$ 의 존재 여부와 상관 없음이 보여졌다. 따라서, 본 연구는 MCT가 남성 생식기관인 부정소에서 정자 성숙과 저장을 위한 적절한 환경을 형성함으로써 남성 생식력의 유지에 관여 할 수 있음을 시사한다.

(색인어 : Epididymis, Monocarboxylate transporter, Basigin, Embigin)

\section{I . INTRODUCTION}

The epididymis is a part of the excurrent ducts in male reproductive tract. The epididymis is a convoluted tubule, which lies between the efferent ductules (ED) and vas deferens. The epididymis is divided into three parts, caput (head), corpus (body), and caudal (tail) epididymis, based on morphological, histological, and functional characteristics (Cosentino and Cockett, 1986). The epididymis plays a number of important roles in male reproduction, including maturation and storage of spermatozoa (Turner, 1979). A various factors, such as sex steroids and peptide hormones, involve in establishment of microenvironment for sperm maturation in the epididymis. Such micro-milieu in the epididymis is frequently regulated by activities of diverse ion transporters and / or water channels, which eventually control homeostasis of the epididymal

Corresponding author : Ki-Ho Lee, Department of Biochemistry and Molecular Biology, College of Medicine, Eulji University, 143-5 Yongdoo-dong, Joong-goo, Daejeon, 301-110, Korea. Tel : 82-42-259-1643, Fax : 82-42-259-1649, E-mail : kiholee@eulji.ac.kr 
fluid and function of the epididymis (Brown et al., 1997; DaSilva et al., 2006).

Monocarboxylate transporters (MCTs) are protoncoupled transporters, which facilitate the movement of lactate, pyruvate, and other monocarboxylate across plasma membrane. To date, 14 MCT isoforms (MCT1-14) have been identified (Halestrap and Price, 1999; Halestrap and Meredith, 2004), and physiological functions of MCT1 and 4 are well characterized (Halestrap and Price, 1999; Halestrap and Meredith, 2004). While the expression of MCT1 is detected most of tissues, other MCT isoforms are present in limited tissues. For example, MCT2 is present in brain and kidney, and MCT3 is strictly expressed in retina (Halestrap and Meredith, 2004). In the male reproductive tract, the testis possesses MCT1, 2, and 4 (Branuchi et al., 2005; Nakai et al., 2006). The presence and differential expression of MCT1, 2, 3, 4, and 8 have been observed in the efferent ductules (ED) of postnatally developing rat from a previous study (Lee et al., 2007). In addition, a recent study showed possible estrogen receptor (ER) a-mediated regulation of MCT1 expression in the ED(Lee et al., 2007). In the epididymis of adult rat, the presence of MCT1 and 2 has been demonstrated from other studies (Garcia et al., 1995; Nakai et al., 2006). However, expression of other MCT isoforms and function of MCTs in the epididymis have not been determined yet.

Proper localization and activity of MCT1-4 require two auxiliary proteins, basigin (Bsg, a.k.a. EMMPRIN or CD147) and embigin (a.k.a. gp70) which are plasma membrane glycoproteins (Philp et al., 2003; Deora et al., 2005; Wilson et al., 2005). Loss of Bsg function results in decreases of MCT1, 3, and 4 expression in retina (Philp et al., 2003) and in altered distribution of MCT1 in the efferent ductules and muscle (Nakai et al., 2006). A direct association of embigin with MCT2 for expression and plasma membrane localization has been demonstrated in a kidney cell line, COS (Wilson et al., 2005). Expression Bsg in the ED of the male reproductive tract has been demonstrated from previous studies (Lee et al., 2007; Nakai et al., 2006). Interestingly, Bsgknockout male mouse is sterile, indicating a functional role of Bsg in male reproduction (Toyama et al., 1999). However, despite evidences showing the presence of MCT1 and 2 in the epididymis (Garcia et al., 1995; Nakai et al., 2006), the expression of Bsg and embigin in the epididymis has not been elucidated in detail.

The present study was focused to show the mRNA expression of various MCT isoforms (MCT1, 2, 3, 4, and 8) and regulatory proteins (Bsg and embigin) in each epididymal region (caput, corpus, and caudal) by real-time polymerase chain reaction (PCR). In addition, expression pattern of these molecules in the epididymis during postnatal development was determined. Moreover, employing immunohistochemistry, ERa knockout (aERKO) mouse was utilized to reveal if the presence of functional ERa is necessary for MCT1 expression in the epididymis, as seen in the ED from a previous report (Lee et al., 2007).

\section{П. MATERIALS AND METHODS}

\section{Animals and tissue preparation}

Male Sprague Dawley rats were obtained from Samtako (OSan, S. Korea), and individually kept in separate cages under controlled conditions. Food and water were given ad libitum for entire experimental period. Total 24 animals were divided into 4 experimental groups; 1) 7 days of age $(n=8), 2) 14$ days of age $(n=6), 3) 30$ days of age $(n=5)$, and 4) 90 days of age $(n=5)$. At a proper age, animals were anesthetized by $\mathrm{CO}_{2}$ stunning, and the entire male reproductive tract was isolated. In cold PBS, the epididymis was 
isolated, and each part of epididymis was separated from others. After quick freezing in liquid nitrogen, the tissues were stored in $-80^{\circ} \mathrm{C}$ until used for total RNA isolation.

Homozygous wild type (WT; C57BL65/129SVJ) and its sibling estrogen receptor (ER) a knockout (aERKO) male mice were obtained from a breeding colony maintaining at University of Illinois at Urbana-Champaign. Experimental animals were randomly divided into 4 age groups; 10 days-old WT $(n=3)$ and aERKO $(n=4), 18$ daysold WT (n=3) and aERKO (n=4), 35 days-old $\mathrm{WT}(\mathrm{N}=4)$ and $\operatorname{aERKO}(\mathrm{n}=4)$, and 60 days-old $\mathrm{WT}(\mathrm{n}=3)$ and $\operatorname{aERKO}(\mathrm{n}=3)$. Mice were killed by cervical dislocation, and the male reproductive tract was isolated and fixed in Bouin's solution for detection of MCT1 in the epididymis by immunohistochemistry (IHC). The kidney was used as a positive control of IHC.

\section{Total RNA isolation and real-time PCR analyses}

Total RNAs were isolated from the tissues by using easy-Blue total RNA extraction solution (iNtRON Biotech, Sungnam, S. Korea) and a polytron homogenizer (Fisher Scientific, Pittsburgh, USA). Total RNAs were dissolved in RNA storage buffer (Ambion, Austin, USA), and the purity and concentration of the total RNA were spectrophotometically measured. The qualities of the total RNA were checked by gel electrophoresis. The total RNAs were kept at $-80^{\circ} \mathrm{C}$ until utilized for real-time PCR. Oligonucleotide primers for real-time PCR were designed either on computer (Primer 3 software, Whitehead Institute/ MIT Center for Genomes Research, USA) or from published information. Sequences and PCR conditions of molecules tested in the present study are summarized in Table. 1.

The reverse-transcription (RT) procedure was carried out according to the manual in ImProm-
$\mathrm{II}^{\mathrm{TM}}$ reverse transcription system (Promega, Madison, USA). Briefly, $1 \mu \mathrm{g}$ of total RNA was reversetranscribed in total volume of $20 \mu \mathrm{l}$ using oligodT primer. RT reaction was performed at $25^{\circ} \mathrm{C}$ for $5 \mathrm{~min}, 42^{\circ} \mathrm{C}$ for $1 \mathrm{hr}$, and $70^{\circ} \mathrm{C}$ for $15 \mathrm{~min}$. For real-time PCR, $1 \mu \mathrm{l}$ of cDNA was used to make a $25 \mu \mathrm{l}$ reaction mixture, which includes $0.75 \mathrm{U}$ of Go Taq DNA polymerase (Promega, Madision, USA), $5 \mu 1$ of $5 \times$ buffer, $0.2 \mathrm{mM}$ dNTPs (Promega, Madision, USA), $2.5 \mu \mathrm{l}$ of 3000X SYBR Green (BMA, Rockland, USA), and 10 pmol of each primer. The PCR program employed an initial step of $95^{\circ} \mathrm{C}$ for $5 \mathrm{~min}$ for pre-denaturation, followed by denaturation at 94 ${ }^{\circ} \mathrm{C}$, annealing, and extension at $72^{\circ} \mathrm{C}$ of cycles using PTC-200 Chromo4 real-time system(BioRad Laboratories, Hercules, USA). The final extension at $72^{\circ} \mathrm{C}$ for 10 min was carried out for the PCR. As PCR quality controls, no RNA, no CDNA, and no primer sets were included in the PCR. The PCR products were visualized on $1.2 \%$ agarose gel and photographed under UV using an image documentation system (Vilber Lourmat, Marnela-Vallée, France). For real-time PCR assay, GAPDH was used as an internal PCR control.

\section{Immunohistochemistry of MCT1}

The male reproductive tract of WT and a ERKO mice was stored in Bouin's fixative at room temperature for 12 14 hours. The epididymis was separated from the testis and rest of male reproductive tract. The entire epididymis was dehydrated in a series of ethanol, cleaned in xylene, and embedded in paraffin. Tissue sections at $5 \mu \mathrm{m}$ thickness were deparaffinized in xylene and rehydrated in a series of ethanol. Then, sections were microwaved for $10 \mathrm{~min}$ in $0.01 \mathrm{M}$ citrate buffer, $\mathrm{pH}$ 6.0, for antigen retrieval, followed by inactivation of endogenous peroxidase with $0.3 \% \mathrm{H}_{2} \mathrm{O}_{2}$ in methanol for $15 \mathrm{~min}$. Nonspecific binding was prevented with incubation 
Table 1. Primer sequences and conditions for real time PCR

\begin{tabular}{|c|c|c|c|c|c|}
\hline MCTs & $\begin{array}{l}\text { Forward primer sequence } \\
\qquad\left(5^{\prime}-3^{\prime}\right)\end{array}$ & $\begin{array}{l}\text { Reverse primer sequence } \\
\qquad\left(5^{\prime}-3^{\prime}\right)\end{array}$ & $\begin{array}{l}\text { Product size } \\
\text { (bp) }\end{array}$ & $\begin{array}{c}\text { GenBank } \\
\text { access number }\end{array}$ & $\begin{array}{l}\text { Tm } \\
\left({ }^{\circ} \mathrm{C}\right)\end{array}$ \\
\hline MCT 1 & $\begin{array}{c}\text { AGAAGTCAGCCTTCCTC } \\
\text { CTTT } \\
(1071-1091) \\
\end{array}$ & $\begin{array}{c}\text { CCACAAGCCCAGTATGT } \\
\text { GTAT } \\
(1444-1464) \\
\end{array}$ & 394 & NM_012716 & 60 \\
\hline MCT 2 & $\begin{array}{c}\text { GGCCTTCGGTAGGATTA } \\
\text { ATAG } \\
(1095-1115)\end{array}$ & $\begin{array}{c}\text { ATGCCTGATGATAACAC } \\
\text { GACT } \\
(1441-1461)\end{array}$ & 367 & X97445 & 60 \\
\hline MCT 3 & $\begin{array}{c}\text { GCTCTGAAGAACTATGA } \\
\text { AATCA } \\
(1352-1373) \\
\end{array}$ & $\begin{array}{c}\text { GTGAACAGGGTCTAACA } \\
\text { TATTG } \\
(1757-1778) \\
\end{array}$ & 427 & AF059258 & 53 \\
\hline MCT 4 & $\begin{array}{c}\text { TGCGGCCCTACTCTGTC } \\
\text { TAC } \\
(881-900) \\
\end{array}$ & $\begin{array}{c}\text { TCTTCCCGATGCAGAAG } \\
\text { AAG } \\
(1017-1036) \\
\end{array}$ & 369 & AF178954 & 60 \\
\hline МСТ 8 & $\begin{array}{c}\text { TCССТТССТСАТСАААA } \\
\text { TGC } \\
(759-775) \\
\end{array}$ & $\begin{array}{c}\text { CGTAGGGGACGAAGTA } \\
\text { ACCA } \\
(1017-1036) \\
\end{array}$ & 281 & AJ496570 & 60 \\
\hline Bsg & $\begin{array}{c}\text { CAGGATCAAGGTGGGA } \\
\text { AAGA } \\
(330-349)\end{array}$ & $\begin{array}{c}\text { CACTTGGGCTGGGATAA } \\
\text { GAA } \\
(944-963)\end{array}$ & 634 & NM_012783 & 60 \\
\hline Embigin & $\begin{array}{c}\text { CCGGTACAGAAAAACG } \\
\text { GACT } \\
(1044-1063) \\
\end{array}$ & $\begin{array}{c}\text { CGGATGTTCTCCAATGA } \\
\text { ATG } \\
(1135-1154) \\
\end{array}$ & 111 & NM_053719 & 60 \\
\hline GAPDH & $\begin{array}{c}\text { CCCCTGGCCAAGGTCAT } \\
\text { CCATGACAACTTT } \\
(540-569) \\
\end{array}$ & $\begin{array}{c}\text { GGCCATGAGGTCCACCA } \\
\text { CCCTGTTGCTGTA } \\
(1023-1052) \\
\end{array}$ & 513 & X02231 & 60 \\
\hline
\end{tabular}

MCTs : monocarboxylate transporters ; Bsg : Basigin, aka. CD147 and EMMPRIN

Numbers in parenthesis of primer sequences indicate the positions of bases in GenBank sequences.

of sections in $10 \%$ normal goat serum for 30 min at room temperature. Primary antibody, a chicken anti-MCT1 (Chemicon International, Temecula, CA), at 1:200 dilution was placed on sections and incubated in a humidified chamber at $4^{\circ} \mathrm{C}$ for overnight. After washing in PBS, sections were treated with 1:200 HRP-labeled goat antichicken IgG (Kirkegaard and Perry Laboratories, Gaithersburg, MD) at room temperature for $1 \mathrm{hr}$. Positive immuno-reaction was detected by a mixture of 3,3'-diaminobenzidine (DAB; Sigma, St. Louis, MO), $0.05 \mathrm{M}$ Tris-HCl buffer, and 5\% $\mathrm{H}_{2} \mathrm{O}_{2}$. The sections were counterstained with hematoxylin, followed by dehydration in a series of ethanol. For the negative control, normal serum at 1:200 dilution was placed on the section. The immunostaining was evaluated with images captured by digital camera (Olympus CoolSNAP cf color/OL camera; Olympus America, Melville, NY) using RSImage version 1.1 software (Roper Scientific, Duluth, GA). The photographic images were processed in PhotoShop software (Adobe Systems, San Jose, CA).

\section{Data presentation and statistical analyses}

The RT reaction and PCR for each epididymal region at an age group were performed in triplicate to obtain a mean value and standard deviation. Expression of molecules tested in the present study was normalized with GAPDH. Data of mRNA abundance of each molecule were expressed relative to 7 days of age as arbitrary unit. Mean differences among the age groups for 
each molecule in an epididymal region were compared using one-way ANOVA, followed by Tukey's test. In all cases, results were considered significant if $\mathrm{P}<0.05$.

\section{RESULTS}

1. Regional expression of MCT1 and MCT2 in the epididymis of rat during postnatal development

Expression of MCT1 and MCT2 mRNAs in the epididymis of male rat is shown in Fig. 1. Even though the levels of MCT1 mRNA were different among regions of the epididymis, MCT1 expression was gradually increased by age, followed by a transient decrease at 90 days of age (Fig. 1A). The highest expression of MCT1 in each epididymal region was detected at 30

[A]
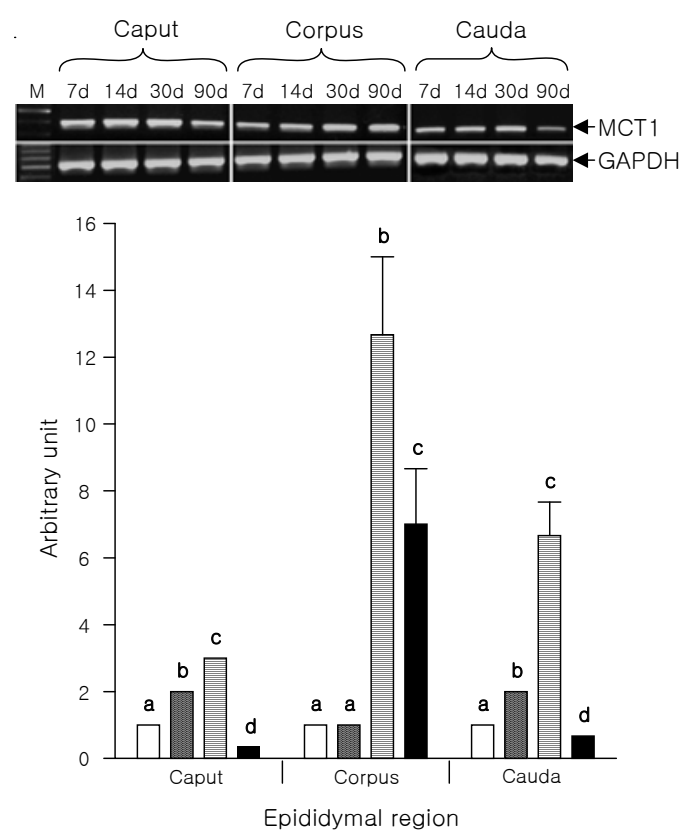

days of age (Fig. 1A). Expression pattern of MCT2 was different to its of MCT1 (Fig. 1B). In caput and caudal epididymis, the highest expression of MCT2 mRNA was observed at 14 days of age, followed by gradual decrease at 30 days and 90 days of age (Fig. 1B). However, expression of MCT2 mRNA in corpus epididymis was significantly increased at 14 days and 30 days of ages (Fig. 1B). The most abundance of MCT2 mRNA in corpus epididymis was found at 90 days of age (Fig. 1B).

2. Segmental expression of MCT3 and MCT4 in the epididymis of male rat during postnatal development

Differential expression of MCT3 mRNA in the epididymis according to ages was similar, regardless the epididymal regions (Fig. 2A). The highest

[B]
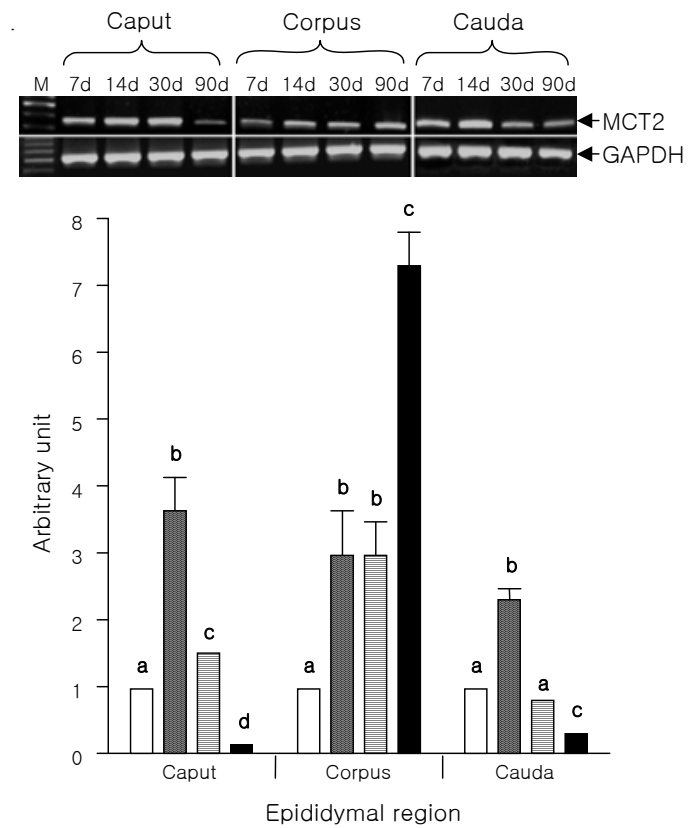

Fig. 1. mRNA expression of MCT1 $[A]$ and $M C T 2[B]$ in the epididymis of rats during postnatal development. M: 100bp marker. Different letters indicate significant differences among means within each segment of the epididymis $(P<0.05)$. Bars indicate the standard deviations. MCT: monocarboxylate transporter. ( $\square$ : 7 days of age, 14 days of age, 目: 30 days of age, and $\square$ : 90 days of age). 
$[\mathrm{A}]$
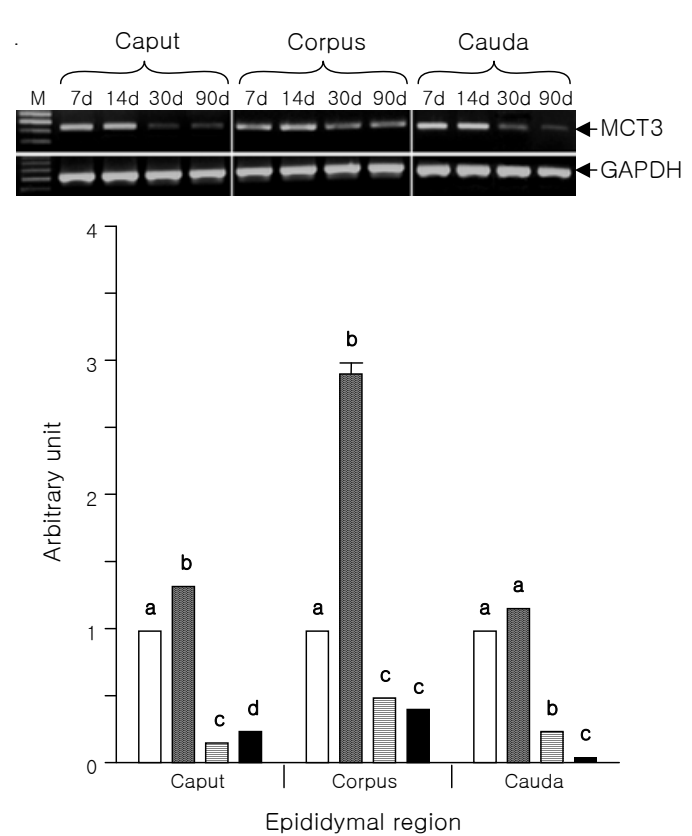

[B]
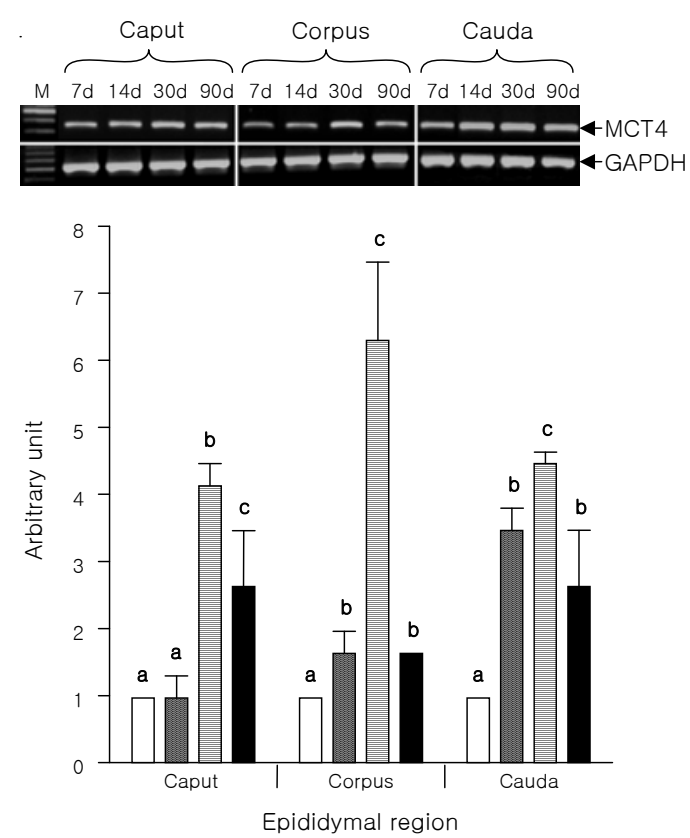

Fig. 2. Expression of MCT3 $[A]$ and MCT4 $[B]$ mRNAs in the epididymis of rats during postnatal development. M: 100bp marker. Different letters indicate significant differences among means within each segment of the epididymis $(P<0.05)$. Bars indicate the standard deviations. MCT: monocarboxylate transporter. ( $\square$ : 7 days of age, $\otimes: 14$ days of age, 目: 30 days of age, and $\mathbf{\square}$ : 90 days of age).

expression of MCT3 mRNA was found at 14 days of age, even though the extent of increases of MCT3 mRNA abundance was different among the epididymal segments (Fig. 2A). Expression of MCT3 mRNA was transiently decreased at 30 days (Fig. 2A). The lowest level of MCT3 mRNA in each epididymal part was found at 90 days of ages (Fig. 2A). Expression pattern of MCT4 mRNA in the epididymis during postnatal development is shown in Fig. 2B. Regardless regions of the epididymis, the highest levels of MCT4 mRNA were detected at 30 days of age (Fig. 2B). Significant increases of MCT4 mRNA expression at 14 days of age were detected in corpus and caudal epididymis (Fig. 2B). The expression of MCT4 mRNA was significantly reduced at 90 days of age, compared to its at 30 days of age (Fig. 2B).
3. Differential expression of MCT8, basigin, and embigin in the epididymis of rat during postnatal development

Expression profile of MCT8 and Bsg in the epididymis during postnatal development is shown in Fig. 3. In caput epididymis, the expression of MCT8 was gradually decreased as animals became aged(Fig. 3A). However, in corpus and caudal epididymis, expression level of MCT8 mRNA was increased at 14 days of age, followed by transient decreases at 30 days and 90 days of ages (Fig. 3A). Expression of Bsg mRNA in the epididymis showed regional-specific patterns (Fig. 3B). Abundance of Bsg mRNA in caput epididymis remained in same level throughout postnatal development, while expression of Bsg mRNA in corpus epididymis was the highest at 
$[\mathrm{A}]$
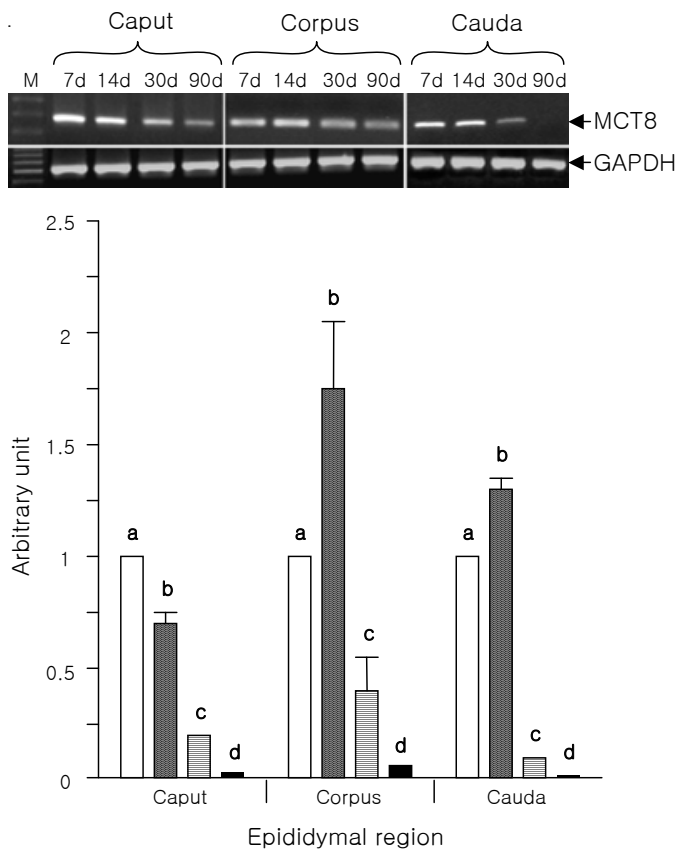

[B]
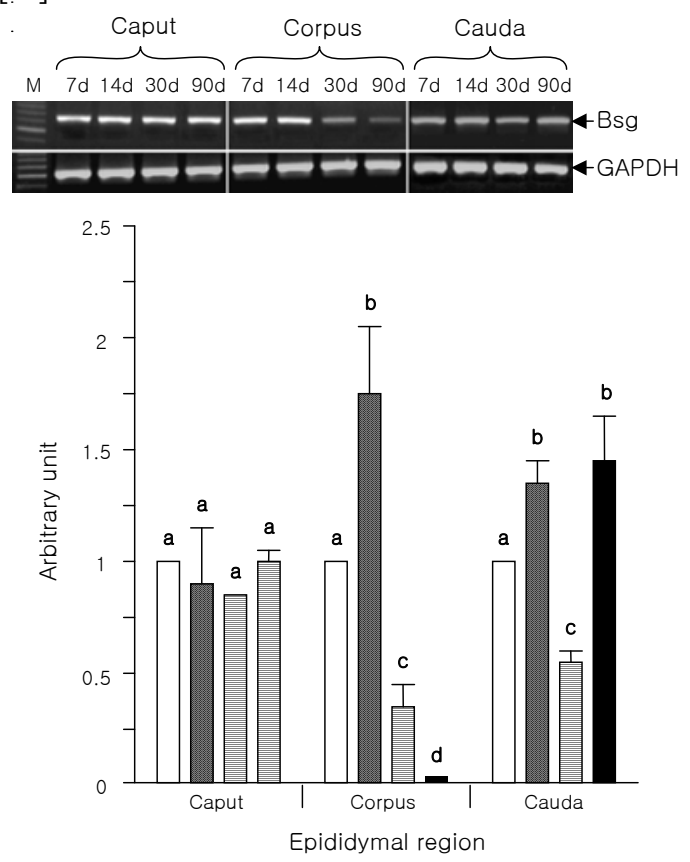

Fig. 3. Differential expression of MCT8 $[A]$ and Bsg $[B]$ mRNAs in the epididymis of rats during postnatal development. M: 100bp marker. Different letters indicate significant differences among means within each segment of the epididymis $(P<0.05)$. Bars indicate the standard deviations. MCT: monocarboxylate transporter. ( $\square: 7$ days of age, 14 days of age, 目: 30 days of age, and $\mathbf{\square}: 90$ days of age).

14 days of age, followed by transient decreases at 30 days and 90 days of ages (Fig. 3B). In caudal epididymis, the fluctuation of Bsg mRNA expression was observed at different ages of postnatal development, the highest levels at 14 days and 90 days of ages and the lowest level at 30 days of age (Fig. 3B).

The expression and presence of embigin mRNA was also detected in entire epididymal regions (Fig. 4). Tremendous increases of embigin mRNA levels were observed at 14 days, 30 days, and 90 days of age, compared to the level of embigin mRNA at 7 days of age (Fig. 4). Interestingly, the extent of increase of embigin mRNA level was enormous, about 8 - 1500 folds (Fig. 4). In caput and caudal epididymis, the highest expression levels of embigin mRNA were detected at 30 days of age, followed by transient decreases at 90 days of age (Fig. 4). However, expression pattern of embigin mRNA in corpus epididymis was age-dependent, with a dramatic increase of embigin mRNA level at 90 days of age (Fig. 4).

\section{Immunolocalization of MCT1 in the epididymis of WT and aERKO mice}

Strong immuno-reaction of MCT1 was observed in the epididymis of WT and aERKO mice (Fig. 5). There was no difference in expression pattern of MCT1 in the epididymis between WT and a ERKO mice (data not shown). However, regionand age-specific expressions of MCT1 protein were found in the epididymis of mouse. At 10 days of age, no immuno-positive reaction of MCT1 was detected along the entire epididymis 

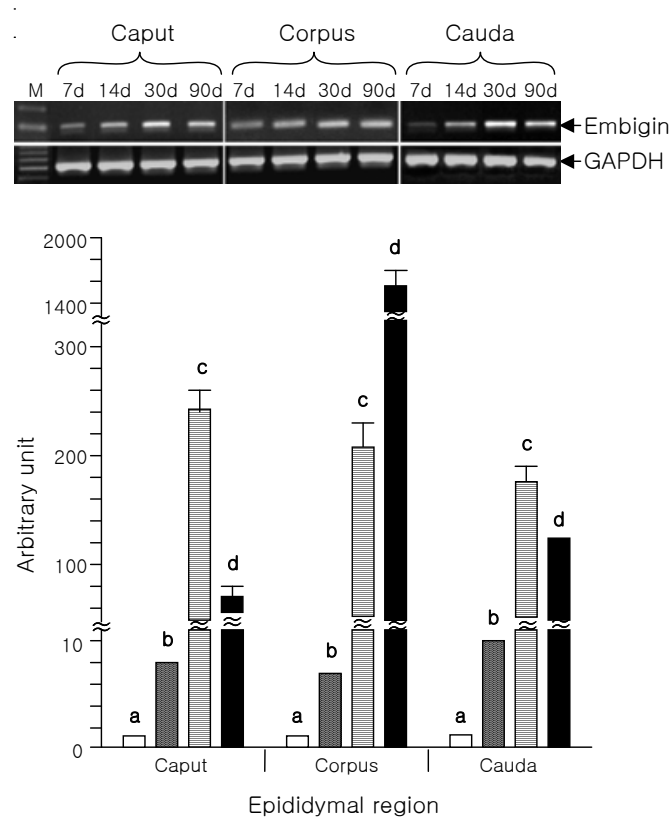

Fig. 4. Differential expression of embigin mRNA in the epididymis of rats during postnatal development. M: 100bp marker. Different letters indicate significant differences among means within each segment of the epididymis $(P<0.05)$. Bars indicate the standard deviations. MCT: monocarboxylate transporter. ( $\square$ : 7 days of age, 14 days of age, 目: 30 days of age, and $\mathbf{\square}: 90$ days of age).

(Fig. 5a, b, and c). Differential expression of MCT1 in the epididymis was detected at 18 days of age (Fig. 5d, e, and f). No immuno-reaction of MCT1 was seen in the caput epididymis (Fig. $5 d$ ), while sterocilia of the epididymal epithelia in the corpus and caudal regions were immunopositive (Fig. 5e and f). At 35 days of age, the epithelium in the caput epididymis was immunonegative for MCT1 (Fig. 5g). However, the strong positive staining of MCT1 was observed on spermatozoa in the lumen of the caput epididymis (Fig. 5g). Strong staining of MCT1 was appeared on sterocilia of corpus and caudal epididymis (Fig. $5 \mathrm{~h}$ and i). The epithelium of the caput

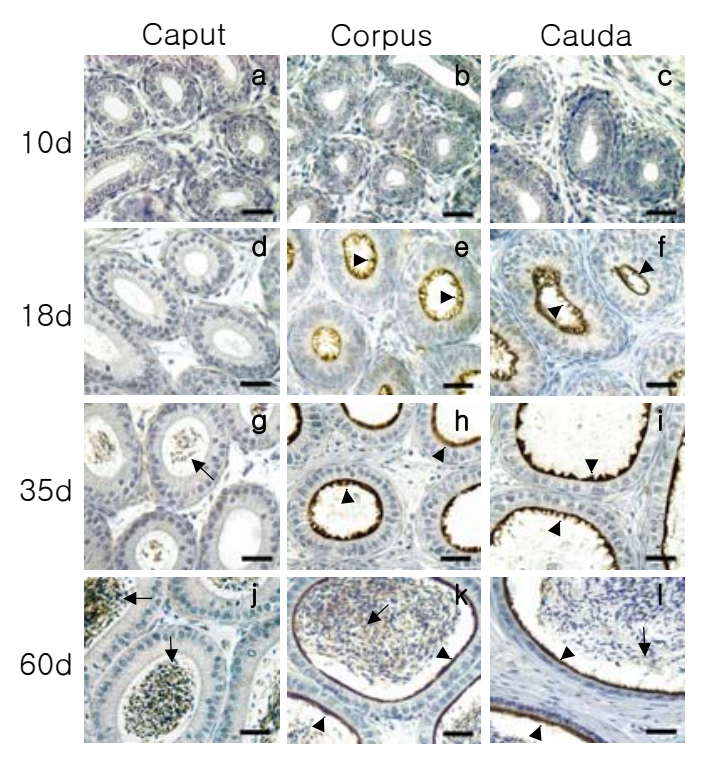

Fig. 5. Immunohistochemical detection of MCT1 in the epididymis of WT mouse during postnatal development. No positive immuno-reaction for MCT1 shows in the entire epididymis at 10 days of age ( $a, b$, and $c)$. At 18 days old of age, positive immunostaining for MCT1 is restricted on sterocilia (arrow heads) of the corpus (e) and caudal (f) epididymis. In the caput epididymis at 35 days-old, the epithelium is still immuno-negative for MCT1, but spermatozoa in the lumen are immuno-positive for MCT1 (g, arrow). Strong immuno-reaction of MCT1 is shown on sterocilia (arrow heads) of the corpus (h) and caudal (i) epididymis at 35 days of age. At 60 days of age, positive immunostaining of MCT1 shows on sterocilia (arrow heads) of the corpus (k) and caudal (I) epididymis. Note that staining intensity of MCT1 on spermatozoa in the epididymal lumen becomes gradually decreased along the epididymis ( $\mathrm{j}, \mathrm{k}$, and $\mathrm{l}$, arrow heads). $10 \mathrm{~d}$ : 10 days, $18 \mathrm{~d}: 18$ days, 35d: 35 days, and 60d: 60 days of age. Bar $=30 \mu \mathrm{m}$.

epididymis at 60 days of age was still immunonegative for MCT1 (Fig. 5j). However, as seen at 35 days old of age, positive staining of MCT1 was detected on sterocilia of corpus and caudal epididymis at 60 days of age (Fig. 5k and l). Spermatozoa in the epididymal lumen were 
immuno-positive for MCT1, but intensity of immuno-staining for MCT1 on spermatozoa was gradually decreased along the epididymis, from caput to caudal epididymis (Fig. 5j, k, and l).

\section{DISCUSSION}

The present study was aimed to determine expression profile of MCT isoforms and two MCT-regulatory proteins (Bsg and embigin) in the epididymis of male reproductive tract. In addition, it was attempted to reveal if estrogen and ERa involve in regulation of MCT1 expression in the epididymis. Results from the present study demonstrate expression of several MCTs in the rat epididymis. Even though some MCTs (MCT1, 3 , and 4) shared similar expression patterns among epididymal regions and postnatal ages, MCT2 and 8, Bsg, and embigin showed distinct expression patterns in age- and region-specific manner. Moreover, the present study showed no direct ERa-mediated regulation of MCT1 expression in the epididymis.

The maturation and storage of sperm in the epididymis are carried out within the different luminal microenvironments existing along the epididymis (Cosentino and Cockett, 1986). Formation of functional differences in distinct segments of the epididymis begins with very early stage of the development and becomes completed at maturity (Rodríguez, et al., 2001). Establishment of different environments in the epididymal segments is chiefly controlled by differential expression of various genes (Cyr et al., 1995; Jervis and Robaire, 2001; Rodríguez, et al., 2001). Segment- and development-specific gene expressions in the epididymis have been well documented in a number of researches (Cyr et al., 1995; Jervis and Robaire, 2001; Rodríguez, et al., 2001; Yuan et al., 2007). The present study also revealed differential expression of several MCT isoforms, Bsg, and embigin mRNAs in the epididymis in age- and region-specific manners. These observations imply that MCTs and related molecules involve in creation of adequate microenvironment in the epididymis. In order to understand a detailed role of MCTs in the epididymis, additional studies are suggested to evaluate gene expression of various MCT isoforms and candidate MCT-regulatory proteins in the epididymis during embryonic and prenatal development.

The MCTs are proton-linked transporters which regulate influx or efflux of monocarboxylic acids into or from the cell (Halestrap and Price, 1999). Movement of monocarboxylates across the cell membrane is important for regulation of intracellular $\mathrm{pH}$ and of metabolism to produce energy in the cell (Halestrap and Price, 1999; Halestrap and Meredith, 2004). A number of physiological functions of MCTs in various tissues have been suggested from earlier researches (Halestrap and Price, 1999). In male reproductive tract, the testis possesses MCT1, 2, and 4, which are thought to involve in Sertoli cell glycolytic activity (Branuchi et al., 2005). In the epididymis, MCT1 and 2 are present in the apical region of the epithelium (Garcia et al., 1994; Garcia et al., 1995; Nakai et al., 2006). However, the physiological role of these MCTs in the epididymis has not been determined yet. Because sperm maturation occurs in the epididymis, it is reasonable to speculate that MCTs would play a role in regulation of epididymal function by maintaining proper environment of epididymal fluid, such as luminal $\mathrm{pH}$ and epithelial metabolism. Interestingly, sperms present in the epididymis also possess MCT1 and 2, with differential expression patterns (Garcia et al., 1994; Garcia et al., 1995). MCT1 on sperm in the caput epididymis is localized on sperm head and disappeared from sperm and appeared on the sterocilia of caudal epididymis (Garcia et al, 1995), agreement with the finding of the present study (Fig. 5). However, MCT2 is 
present on the tails of sperm throughout the epididymis (Garcia et al., 1995). They suggested that MCT1 would participate in monocarboxylate metabolism in sperm (Garcia et al., 1994), while a function of MCT2 in sperm is obscure (Garcia et al., 1995). In addition, Garcia et al. (1994) found that expression of MCT1 switches from to epididymal epithelial cells as sperm traverse along the epididymis. However, immunhistochemical data from the present study revealed the presence of MCT1 on epididymal epithelia at early postnatal development, 18 days of age, in time which no sperm appears in the epididymis. This observation from the current study implies that expression of MCT1 on epididymal epithelia would not relate with the presence of sperm. A detailed molecular mechanism of MCT expression and physiological role(s) of MCTs in the epididymis should be addressed from future studies.

Expressions of MCTs in cells and/or tissues are regulated by various factors, including hormonal factors and/or physiological conditions. Leptin involves in the up-regulation of MCT1 expression in the human intestinal cell line (Buyse et al., 2002). In the brain, insulin-induced hypoglycemia suppresses MCT2 expression (Vavaiya et al. 2007). In male reproductive tract, follicular stimulating hormone (FSH) and testosterone induce a reduction of MCT2 expression in the testis (Boussouar et al., 2003). Regulation of MCT expression in the epididymis has not been elucidated yet. Immunohistochemical study in the present study demonstrated no direct regulation of MCT1 expression in the epididymis by estrogen via ERa (Fig. 5). However, these results do not rule out a possible estrogenregulation on MCT1 expression through ER $\beta$, because aERKO mouse has a functional ERß. Other than estrogen, it is likely that the testicular and/or extra-testicular factor(s) would participate in regulation of MCT expression in the epididymis.
Active secretion of the testicular fluid depends on the time at which formation of Sertoli cell junction occurs (Gondos and Berndston, 1993). The formation Sertoli cell junction begins at 2 3 weeks of age and is completed at 30 days of age (Gondos and Berndston, 1993). Thus, it is speculated that changes in the testicular fluid secretion at different ages would influence gene expression in the excurrent duct, leading to regulation of the function of the epididymis.

Normal function and expression of MCTs require proper localization in cells. In the male reproductive tract, the MCT1 is localized on the basolateral or apical membranes in the ED or epididymis, respectively (Lee et al., 2007; Nakai et al., 2006; Fig. 5 from the present study). Appropriate localization of MCTs in cells is directed by two chaperone molecules, Bsg and embigin. Bsg is required for polarized localization of MCT1, 3, and 4 (Philp et al., 2003; Wilson et al., 2005), and embigin associates with MCT2 (Wilson et al., 2005). Loss of Bsg function results in altered localization and decreased expression of MCT1, 3, and 4 in the retina (Philp et al., 2003; Philp et al., 2004). However, the expression of MCT1 in the epididymis is not affected by the absence of Bsg, even though the localization of MCT1 is altered in the epididymis of Bsg knockout mice (Nakai et al., 2006). These findings imply that Bsg is not a sole factor which directly regulates the expression of MCT1, 3 , and 4. In present study, a clear association of gene expression pattern between Bsg and MCTs has not been observed, except MCT8 and Bsg in corpus epididymis. In addition, the present study showed no correlation between MCT2 and embigin expression. Similar findings have been detected in the ED of the male reproductive tract (Lee et al., 2007). Therefore, it is supposed that expression and localization of MCTs in the male reproductive tract are regulated by a complex of diverse molecular mechanisms, in addition to Bsg 
and embigin. It is noteworthy for a drastic increase of embigin mRNA as aged. Embigin, a glycoprotein belonging to the immunoglobulin superfamily, functions as a regulator of cell/extracellular matrix (ECM) interactions during development and in the homeostasis of normal adult tissues (Guenette et al., 1998). Thus, it is supposed that embigin would play a role in tissue remodeling and/or in segmental differentiation of the epididymis during postnatal development.

In conclusion, for the first time, the present study has revealed that gene expression of various MCT isoforms, Bsg, and embigin in the rat epididymis is differentially regulated in ageand segment-specific manners. In addition, the present study demonstrates no ERa-directed regulation of MCT1 expression in the epididymis. Additional works are suggested to determine molecular mechanisms and factor(s) for the expression and localization of MCTs in the epididymis.

\section{ABSTRACT}

In the present study, real-time PCR was performed to evaluated expression of several isoforms of monocarboxylate transporters (MCTs) and two known MCT regulatory proteins, basigin (Bsg) and embigin, in the epididymis of the male reproductive tract during postnatal development. In addition, ERa-mediated regulation of MCT1 expression in the epididymis was determined with estrogen receptor (ER) a knockout (aERKO) mice by immunohistochemistry. Results from the current study demonstrated differential expression of MCT isoform (MCT 1, 2, 3, 4, and 8), Bsg, and embigin mRNAs in rat epididymis according to postnatal age and epididymal region. In addition, immunohistochemical study of MCT1 revealed the limited localization of MCT1 at apical area of corpus and caudal epididymis. The present study also showed that expression of
MCT1 was not directly regulated by ERa. The findings from the current study suggest that MCTs would involve in establishing adequate microenvironment for sperm maturation and storage in the epididymis, eventually leading to maintenance of male fertility.

(Key words : Epididymis, Monocarboxylate transporter, Basigin, Embigin)

\section{ACKNOWLEDGEMENT}

This work was supported by BumSuk Academic Research Fund of 2007.

\section{REFERENCES}

1. Boussouar, F., Mauduit, C., Tabone, E., Pellerin, L., Magistretti, P. J. and Benahmed, M. 2003. Developmental and hormonal regulation of the monocarboxylate transporter 2 (MCT2) expression in the mouse germ cells. Biol. Reprod. 69:10691078.

2. Branuchi, S., Rauch, M. C., Alfaro, I. E., Cea, C., Concha, I., Benos, D. J. and Reyes, J. G. 2005. Kinetics, molecular basis, and differentiation of L-lactate transport in spermatogenic cells. Am. J. Physiol. Cell. Physiol. 288:C523-534.

3. Brown, D., Smith, P. J. and Breton, S. 1997. Role of V-ATPase-rich cells in acidification of the male reproductive tract. J. Exp. Biol. 200:257-262.

4. Buyse, M., Sitaraman, S. V., Liu, X., Bado, A. and Merlin, D. 2002. Luminal leptin enhances CD147/MCT-1-mediated uptake of butyrate in the human intestinal cell line Caco2-BBE. J. Biol. Chem. 277:28182-28190.

5. Cosentino, M. J. and Cockett, A. T. 1986. Structure and function of the epididymis. Urol. Res. 14:229-240.

6. Cyr, D. G., Robaire, B. and Hermo, L. 1995. Structure and turnover of junctional complexes between principal cells of the rat epididymis. Microsc. Res. Tech. 30:54-66.

7. DaSilva, N., Piétrement, C., Brown, D. and Breton, S. 2006. Segmental and cellular expression 
of aquaporins in the male excurrent duct. Biochim. Biophys. Acta. 1758:1025-1033.

8. Deora, A. A., Philp, N., Hu, J., Bok, D. and Rodriguez-Boulan, E. 2005. Mechanisms regulating tissue-specific polarity of monocarboxylate transporters and their chaperone CD147 in kidney and retinal epithelia. Proc. Natl. Acad. Sci. USA. 102:16245-16250.

9. Garcia, C. K., Goldstein, J. L., Pathak, R. K., Anderson, R. G. And Brown, M. S. 1994. Molecular characterization of a membrane transporter for lactate, pyruvate, and other monocarboxylates: implications for the Cori cycle. Cell. 76:865-873.

10. Garcia, C. K., Brown, M. S., Pathak, R. K. and Goldstein, J. L. 1995. cDNA cloning of MCT2, a second monocarboxylate transporter expressed in different cells than MCT1. J. Biol. Chem. 270: 1843-1849.

11. Gondos, B. and Berndston, W. E. 1993. Postnatal and pubertal development in the Sertoli cell, L. D. Russel. and Griswold, M. D. (Eds.), Cache River Press, Clearwater, U.S.A. p.115.

12. Guenette, R. S., Sridhar, S., Herley, M., Mooibroek, M., Wong, P. and Tenniswood, M. 1998. Embigin, a developmentally expressed member of the immunoglobulin super family, is also expressed during regression of prostate and mammary gland. Dev. Biol. 155:307-314.

13. Halestrap, A. P. and Price, N. T. 1999. The proton-linked monocarboxylate transporter (MCT) family: structure, function, and regulation. Biochem. J. 343:281-299.

14. Halestrap, A. P. and Meredith, D. 2004. The SLC16 gene family-from monocarboxylate transporters (MCTs) to aromatic amino acid transporters and beyond. Eur. J. Physiol. 447:619-628.

15. Jervis, K. M. and Robaire, B. 2001. Dynamic changes in gene expression along the rat epididymis. Biol. Reprod. 65:696-703.

16. Lee, K-H., Choi, I. H., Chung, C. S. and Chang, J. S. 2007. Expression of monocarboxylate transporters (MCTs) and basigin and estrogen receptor a (ERa)-mediated regulation of MCT1 expression in the efferent ductules of male reproductive tract during postnatal development. J.
Anim. Sci \& Technol. (Kor.) 49:309-320

17. Nakai, M., Chen, L. and Nowak, R. A. 2006. Tissue distribution of basigin and monocarboxylate transporter 1 in the adult male mouse: a study using the wild-type and basigin gene knockout mice. Ana. Rec. A. Discov. Mol. Cell. Evol. Biol. 288:527-535.

18. Philp, N. J., Yoon, H. and Lombardi, L. 2004. 0Mouse MCT3 gene is expressed preferentially in retinal pigment and choroids plexus epithelia. Am. J. Physiol. 280:C1319-1326.

19. Philp, N. J., Ochrietor, J. D., Rudoy, C., Muramatsu, T. and Linser, P. J. 2003. Loss of MCT1, MCT3, and MCT4 expression in the retinal pigment epithelium and neural retina of the 5A11/basigin-null mouse. Invest. Ophthalmol. Vis. Sci. 44:1305-1311.

20. Rodríguez, C., Kirby, J. L. and Hinton, B. T. 2001. Regulation of gene transcription in the epididymis. Reproduction. 122:41-48.

21. Toyama, Y., Maekawa, M., Kadomatsu, K., Miyauchi, T., Muramatsu, T. and Yuasa, S. 1999. Histological characterization of defective spermatogenesis in mice lacking the basigin gene. Anat. Histol. Embryol. 28:205-213.

22. Turner, T. T. 1979. On the epididymis and its function. Invest. Urol. 16:311-321.

23. Vavaiya, K. V., Paranjape, S. A. and Briski, K. P. 2007. Testicular regulation of neuronal glucose and monocarboxylate transporter gene expression profiles in CNS metabolic sensing sites during acute and recurrent insulin-induced hypoglycemia. J. Mol. Neurosci. 31:37-46.

24. Wilson, M. C., Meredith, D., Manning Fox, J. E., Manoharan, C., Davies, A. J. and Halestrap, A. P. 2005. Basigin (CD147) is the target for organomercurial inhibition of monocarboxylate transporter isoforms 1 and 4. J. Biol. Chem. 280:27213-27221.

25. Yuan, Q., Guo, Q. S., Cornwall, G. A. and Wang, Y. F. 2007. Age-dependent expression of the cystatin-related epididymal spermatogenic (Cres) gene in mouse testis and epididymis. Asian J. Androl. 9:305-311.

(접수일자 : 2007. 11. 30. / 채택일자 : 2008. 2. 14.) 